\title{
Value Configuration in Higher Education - Intermediate Tool Development for Teaching in Complex Uncertain Environments and Developing a Higher Education Value Framework
}

\author{
By David Wawrzinek \\ Guido Ellert ${ }^{\dagger}$ \\ Claas Christian Germelmann
}

This conceptual paper addresses the issue of value creation in the field of higher education and pre-sents a new theoretical perspective by assigning the Service Dominant Logic (SD-logic) and develop-ing a higher education value framework, consisting of ten "foundational premises" for a better understanding of higher education phenomena. Furthermore, based on the theoretical findings this paper presents the Empirical Research Map as a holistic, intermediate learning- und teaching-tool that provides a navigational aid through the entire socio-scientific empirical research process and visualizes all interlinked research steps on a single DIN-A-3-sheet. The empirical research process is affected by high complexity and thus uncertainty. Students have to make many decisions and have problems in anticipating long-range and secondary effects. From a didactic perspective, the Empirical Research Map facilitates making important decisions, the anticipation of long-range and secondary effects and therefore provides additional value to researchers, teachers and students in the social sciences.

Keywords: higher education, intermediate teaching tool, mapping, psychology of learning, ser-vice, value configurations, visualization.

\section{Introduction - \\ Growth of Complexity in Higher Education as General Context}

According to a study, titled "Overstrained, disappointed, wrong decision or strategically - A typology of prematurely exmatriculated Bachelor students" (Blüthmann, Lepa, \& Thiel, 2012) 25 percent of polled, prematurely exmatriculated students stated being overstrained. These students lack general learning skills and subject-specific skills, and have also failed an above average number of tests. Through the structural changes in the European higher education landscape in the course of the Bologna process, and the concomitant introduction of the bachelor and master degree programs, as well as the efforts to establish a single European higher education area, the complexity of

\footnotetext{
* Head of Study Programs, Sport Management Academy Bayreuth GmbH, Germany.

${ }^{\dagger}$ Head of Competence Centre Business Psychology, Business School, Macromedia University of Applied Sci-ences, Germany.

${ }^{\ddagger}$ Professor and Chair of Marketing, University of Bayreuth, Germany.
} 
studying has increased additionally, inter alia because of work overload, increased testing density, obligatory stays abroad, a lack of time and too much content choice (Blüthmann, Lepa, \& Thiel, 2012, p.10). At this juncture, students have to be able to put together independently, individual cognitive modules so as to form and understand an overall system or course of studies, in order to avoid failing. According to Kainz (2011, p.73) students complain about curriculum overload, increased stress and pressure. Wörfel, Gusy and Lohmann (2014, p.49) in turn state that during the study period dealing with one's own inadequacies and failures is of particular relevance, since students, also because of the Bologna reform, are subjected to significant performance pressure and are exposed to critical feedback. Hence, innovative and systematic teaching and learning processes and appropriate tools for understanding a system seem to become even more important for managing this increased complexity at the best. Higher education is facing an intense process of change with rising complexity within academic education, as it becomes increasingly specialized and fragmented. At the same time, new, ever more sophisticated and rapidly changing occupational fields arise, to which higher education facilities have to respond with suitable up-to-date offers that provide a current connection to practice. A good example is the occupational field of "Media Management", in which academically mediated content timeliness and relevance is characterized in many areas by a very short half-life. Generally, it can be said that in a globalized and dynamized world increased complexity now affects all areas of life. Specifically, the working environments are increasingly complex - with the aim of making things easy for customers. Sargut and McCrath (2011) explain this scenario in terms of the information technology revolution. According to Castells (2010), this began in the US around 1970, is progressing at breakneck speed, accelerating globally and has expanded into all spheres of social and economic activity. In addition, a new form of industrialization (industry 4.0, the Internet of Things) is arising, and advanced I\&C technologies and a new quality of informatization (Boes, Kämpf, \& Marrs, 2013, p.3) lead to fundamental changes, bringing new and major challenges. Increased complexity results in decisions being more difficult to make, because the anticipation of effects becomes ever more complicated. Thus, the more complex a system, the more difficult and serious an actor's decisions seem and may really be, because "it is very difficult, if not impossible, for an individual decision maker to see an entire complex system" (Sargut \& McCrath, 2011). At the same time, there is an increasing risk of making mistakes with surprising, unpredictable and unintended consequences, which in extreme cases lead to failure. In this respect models are useful that consider the potential consequences and capture all dimensions of risk. In management, therefore, tools such as the balanced scorecard (see, e.g., Kaplan $\&$ Norton, 1997) have been developed to reduce complexity in organizations and to deal with it more effectively. However Merton (2013) explains in his article about the evaluation of opportunities and risks of innovations that "our ability to create models rich enough to capture all dimensions of risk is limited". Achi and Berger (2015, p.3) reiterate that a new approach, which 
deals with complex challenges requires breaking out of familiar structures. Considering these findings and developments that, at the same time, emphasize the significance of research in the field of higher education, the question of an appropriate theory logic arises in this context. A logic that provides insights and has the potential to improve our understanding of higher education issues and aids in the development of appropriate tools. Moreover, another research question is: What tools can be constructed that are suitable for reducing the complexity of teaching in the field of higher education, with the aim of facilitating decision making and helping students prevent failure?

These questions will be answered in a two-step-methodical interdisciplinary approach. In the first step, we chose a qualitative research approach. Through several expert group discussions using Delphi technique, it was possible to develop the construct of a strategical higher education value framework. In a second step, the conceptual model of our higher education learning and teaching tool, the Empirical Research Map, is also developed in a qualitative research approach, adopting the logic of constructivism and interpretivism.

Subsequently, the theory logic is explained, which forms the basis for our higher education value framework, which in turn is the basis for the holistic model of the Empirical Research Map. This is a higher education- learning and teaching tool that provides an intermediate navigation aid through the entire socio-scientific empirical research process and visualizes all interlinked research steps on one DIN-A-3-sheet.

\section{Theoretical Logic for Higher Education}

An appropriate and theoretically well-grounded new perspective on higher education is the Service Dominant Logic (SD-logic) (see, e.g.,Vargo \& Lusch, 2004; 2006; 2008; Lusch, 2011), which has its origins in Service Science, marked a turning point in thinking about economic exchange (Woratschek, Horbel, \& Popp, 2014, p.11) and describes service as a "fundamental basis of exchange": "S-D logic establishes an alternative perspective for investigating exchange, which focuses on service - the application of competences for the benefit of another- as the central process for value creation" (Vargo, Lusch, \& Akaka, 2010, p.137).

Higher education can also be seen as a service which is an "application of knowledge and skills" (Akaka et al., 2013, p.3), where value is generated collaboratively from a complex network of different actors including lecturers, students, services and administration staff within the framework of appropriate room facilities and teaching materials. Through "co-creation" (Vargo \& Lusch, 2008, p.2), all involved internal and external stakeholders create value from the services offered by making the best use of their own resources and capabilities (see, e.g., Chandler \& Vargo, 2011, p.40; Sheth \& Uslay, 2007, p. 302-307). According to Ashill, Naumann, Sirdeshmukh and Williams (2013, p.9) "relational value is co-created when the parties involved ... combine their knowledge and skills in order to achieve higher performance than would be 
achieved by working independently". Higher education-training, irrespective of the subject area, is especially aimed at mediating four basic skills for the future. These are understanding and mapping contiguous networks, problemsolving skills when networks are not involved, the ability to work collaboratively and finally, the mediation of ethical values.

Figure 1. Higher Education System- and Course Framework

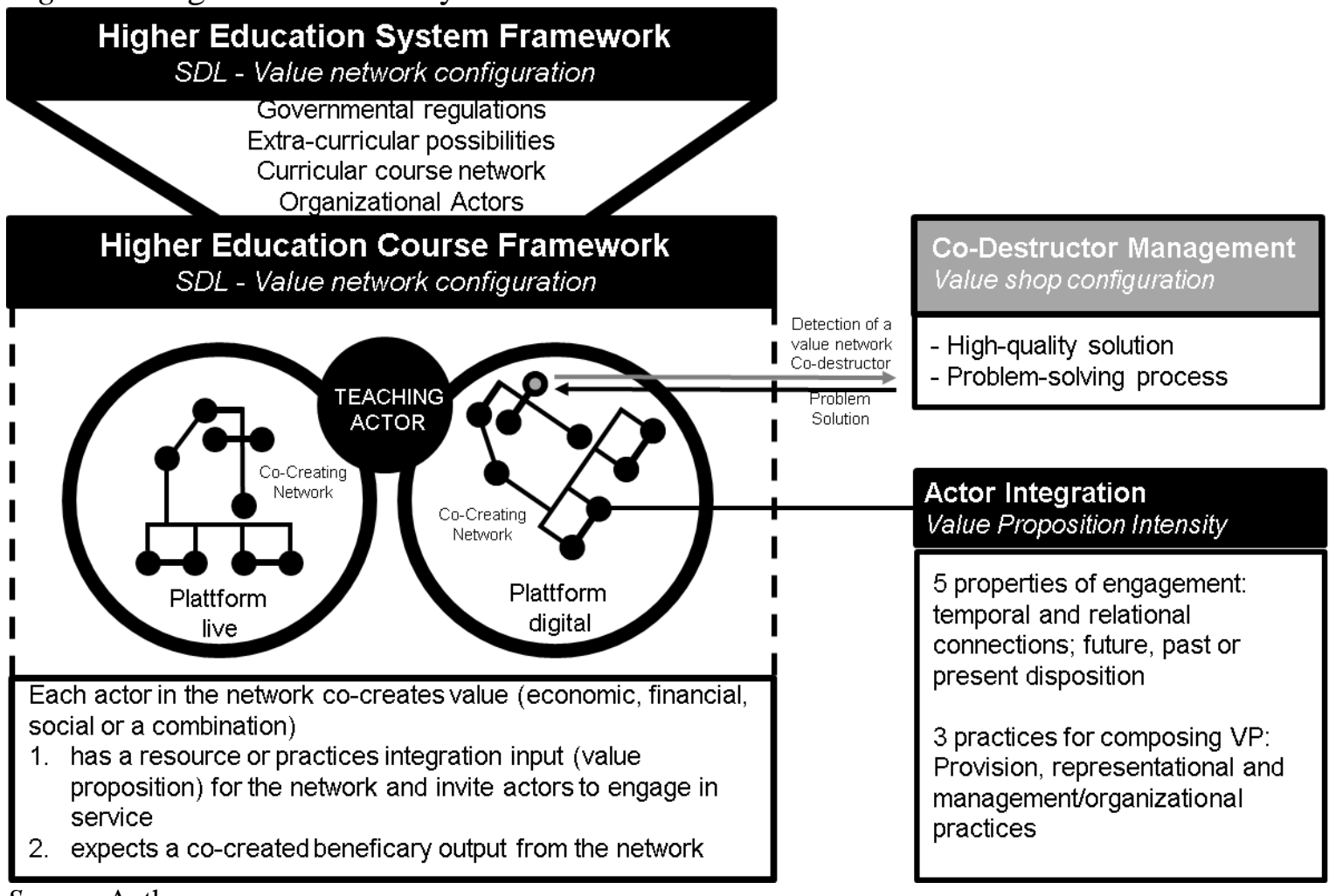

Source: Authors

The value generated in this case is a collaborative learning and teaching process through the participation of diverse actors in education or teaching the relevant competences in order to achieve the training objective, based on the "value network". The three different value creation logics, also known as value configurations, are referred to variously as value chain, value network and value shop (see Porter, 1985; Thompson, 1967; Stabell \& Fjeldstad, 1998, p.415). Chandler and Lusch (2015, p.8) define value propositions "as invitations from actors to one another to engage in service", and state that its intensity can be high or low, furthermore argue that "it is important to note that value propositions are not always successful ... because, nestled in a sea of value propositions, an actor can favorably reply to only a small number of value propositions". They also discuss engagement and propose that it has five properties and that "it is important to understand how value propositions invite engagement" (Chandler \& Lusch, 2015, p.9). The three value configurations differentiate according to the order of required skills and activities of all stakeholders in the value-creation process. The aim is to generate additional value through different strategies (Amit \& Zott, 2001, p.496). Similar to Sports 
Management, the purpose of higher education facilities lies in linking the different stakeholders to another (Woratschek, Horbel, \& Popp, 2014, p.16). Following this logic, it is necessary to consider that "single actors cannot create value at all because value is always the result of a collaborative process between various actors".

\section{The Psychology of Learning}

Learning psychology, which deals with how information is acquired, processed and stored, provides further important insights for a theoretical foundation of the Empirical Research Map. Learning is a psychological process within the long-term memory, of selecting and processing at four levels: cognitive, affective, conative and motoric (see Ellert, Schafmeister, Mueller, Dallwig, \& Phelan, 2014). Rogers (2000, p.22) suggests that students learn in very different ways, and categorized three "types of learners": 1. Visual, 2. Auditory and 3. Kinesthetic or tactical: "Visual learners are stimulated most effectively by the use of a multi-sensory approach provided by movement, color, graphics and sound". Vester (2014), in turn, distinguishes between four types of learners: Auditory, visual, haptic and cognitive. Falk-Frühbrodt (2015), from the Institute for Learning and Advanced Training in Berlin, categorizes six types of learners: Auditory, visual, motoric, communicative, people-oriented and media-oriented. However, it should be noted that the learner type classification should be viewed with some caution. Quast (2011), for example, even denies the very existence of learner styles, because thitherto there, has been no empirical research on the identification of preferred learning styles by specific learning personalities. In addition, she emphasizes:

During the process of learning, success factors exert an influence, which is not reflected in the concept of learner types. These factors include, in particular, previous knowledge, as well as working memory capacity, intellectual prerequisites, the degree of self-efficacy, and motivational factors (e.g., achievement motivation) etc. (author's translation ,Bildungsserver Rheinland Pfalz, 2015, p.3).

Since the learner-type categorization is controversial in the research literature, the latest psychological findings are applied at this point. Some are already in use successfully in sport psychology and allow a precise, empirically founded typology in "state-oriented" and "action-oriented" subjects (Kazén, Kaschel, \& Kuhl, 2008, p. 693). This typology is extremely helpful in the categorization of learner types and the mediation of complex course content, because it offers, from a didactical perspective, new impetus for (re)action by higher education teaching staff, in order to respond more specifically to individual learner patterns of reception. While state-oriented individuals are characterized by extensive brooding over awkward situations and an unintentional fixation on one's own situation, action-oriented individuals are 
characterized by early identification and the correction of one's own mistakes, and situation optimization through proactive behaviour (also see Kuhl, n.d.).

Applying this typology to our subsequently explained specific context, namely teaching complex empirical research processes, it can be concluded that it is probably more difficult for state-oriented students to find their way and to achieve their research goals. Excessive hesitation poses a threat to research, and state-oriented subjects in particular, run the risk of remaining too long at certain research stages, not effectively anticipating potential long-range and short-range effects, and thus suffering success setbacks, which, because of the lack of self-motivation, further intensify uncertainty.

\section{Specific Context: \\ The Socio-Scientific Empirical Research Process as a Complex System}

Innovative, empirical research processes are characterized by particularly high complexity and intensity, thus acting as a reference context in the development of our tool. In deciding this, it was decisive for the quality criteria, that it is applied to as many students as possible, represents a complex system with high uncertainty (general context), is well suited to visualization through mapping techniques (see point "mapping techniques and visualizations reducing complexity") and is appropriate for our expert interviews. The above issues are relevant for our specific context, because, in almost all socioscientific courses of study, there are empirical research modules among the basic ones, and therefore, they are an inherent part of academic basic education. Students are therefore usually confronted with empirical research processes in the first semesters of their undergraduate studies, have to make numerous decisions and familiarize themselves with a wide range of literature on the individual research steps. Often, they then fail, due to lack of overall system understanding and lack of anticipation of long-range and secondary effects. Clark, Howard and Early (2006, p.27) state that "one of the greatest challenges facing education today is to find more effective and efficient ways to support the learning of highly complex knowledge". The empirical research process, with all its links of multiple steps and components, processes and decisions, represents just such a form of highly complex knowledge. According to Sargut and McGrath (2011), complexity is challenging, because in general, actors need to deal with unintended consequences after making decisions and the difficulty is to grasp these consequences properly. At this point, it is important to note that, within a system, everything is linked to everything else and connected. Complex systems are characterized by Dörner $(1979 ; 1983)$ in terms of four key features: dynamism, transparency, polytely (multiplicity of objectives) and interconnectedness. If one of these variables is affected, this has long-range and secondary effects on all other variables within the system. The complexity of a segment of reality is higher, the more features are available, and the more features, the more they are interdependent (see Dörner, 2012). What happens when long-range and secondary effects in the empirical 
research process are not anticipated? Wrong decisions, wrong results, disappointment, frustration and in the worst case, complete failure are possible consequences. Increased task complexity may lead to motivation deficits and negative emotional responses for learners: "As task complexity increases, more learners experience negative emotional reactions and those who lack emotional self-regulatory skill, tend to become angry or depressed and distracted from learning goals" (Clark, Howard, \& Early, 2006, p.32). On the way from identifying a changing context in social reality, defining research questions, choosing a research strategy- and method, to the point of solutiondetermination for the scientific and the business community, numerous decision options and obstacles have to be managed. A comprehensive (research) system understanding, awareness of their role as researchers and decision-makers, as well as problem solving competences, all appear. In considering these findings, it is all the more important to manage complexity and the associated uncertainties in the empirical research process.

\section{How to Solve Complex Problems}

The research area "Complex Problem Solving" provides helpful insights into solving complex problem processes during empirical research projects, through capturing them and on getting them under control (see Dörner, Drewes, \& Reither, 1975; Broadbent, 1977; Dörner \& Wearing, 1995). Frensch and Funke (1995, p.15), whose perspective is firmly rooted in the European tradition on complex problem solving, define it as follows:

Complex problem solving occurs to overcome barriers between a given state and a desired goal state by means of behavioral and/or cognitive, multi-step activities. The given state, goal state, and barriers between given state and goal state are complex, change dynamically during problem solving, and are intransparent. The exact properties of the given state, goal state, and barriers are unknown to the solver at the outset. CPS implies the efficient interaction between a solver and the situational requirements of the task, and involves a solver's cognitive, emotional, personal, and social abilities and knowledge.

The two authors also provide an accurate definition of what exactly constitutes a problem: "A problem must be a. novel, b. complex, c. dynamically changing over time, and d. intransparent". Another definition is provided by Fischer, Greiff and Funke (2012, p.22), who state: "that 'barriers' between the given situation and the desired goal state, i.e., the lack of knowledge, can be further classified according to the amount of a. ignorance of the means/operations applicable, and b. lack of concreteness concerning the goal state". When solving complex problems, both "internal subject factors" (experience, cognitive and noncognitive variables) and "external factors" (problem structure, problem context and environmental factors) play a decisive 
role (Frensch \& Funke, 1995, pp.20). When solving complex problems, Goldstone and Pizlo (2009, p.1) stress the influence of implicit and explicit knowledge and the associated systemic strategy. They describe a human problem-solving process as an interaction of cognition, emotion and conation that ultimately leads to the decision. Fischer, Greiff and Funke (2012, p.36) in turn outline the problem-solving process in three phases. Phase 1 initially deals with a problem and understanding the system. In the second phase, there is an analysis of the complexity and the associated long-range and secondary effects. The third phase finally implies action and control, entailing an understanding of effects. Furthermore they state: "In order to solve complex problems, people usually have to acquire and to apply knowledge about complex systems concerning the systems' structure and dynamics" (Fischer, Greiff, \& Funke, 2012, p.20).

\section{Uncertainty during Research Processes}

Increased complexity causes increased uncertainty and at the same time, an increased occurrence of unforeseen problems. Generally, in today's network society (Castells, 2010), "unpredictable working conditions lead to an increase in personal crises" (translated from Zillien, 2009, p.49). This phenomenon of increasing uncertainty can also be applied to research in higher education. In their role as researchers, students are faced with numerous uncertainties and, for example, have to decide whether they need to conduct quantitative or qualitative research in order to achieve their research goals. In addition, the context and role of the researcher change, which entails rapid rethinking and considering the consequences of action in the context of problem-solving processes. As a research project always requires professional project management, findings from the research areas of projects, risk and uncertainty management are included below, so as to better analyze, structure and penetrate the uncertainties of the empirical research process. In general, it is human nature to seek security, "especially in the face of the unknown" (Achi \& Berger, 2015). According to Van Horne (1966), there is some uncertainty as soon as the probability of a particular event is unknown. Researchers in the field of higher education have to accept this uncertainty during their research process and manage it adequately. Ward and Chapman (2003, p.98) see, in uncertainty management, not only the management of perceptible opportunities, risks and their consequences: "It is about identifying and managing all the many sources of uncertainty which give rise to and shape our perceptions of threats and opportunities". It is also important to note that classic risk management differs from uncertainty management (Stoelsnes \& Bea, 2005). Lokmann and Bash (1993, p.18) point out that uncertainty exists, when a past result of any event is unknown. Risk, however, reflects the likelihood of an unwanted result and has a limited focus on the management of project uncertainties. For this reason, Ward and Chapman (2003, p.105) 
suggest replacing the term "Project Risk Management" with "Project Uncertainty Management". The authors argue as follows:

A weakness in current PRM processes is that they are not readily focused on sources of operational variability in the performance of organizational activities. An "uncertainty management" perspective facilitates such a focus and also draws attention to the need to understand and manage variability in organizational activities that have an input into a number of projects.

In solving uncertainty, Achi and Berger (2015) suggest:

Uncertainty can't be solved with pat procedures; it takes new habits of mind to lead the possible. In our experience, three such habits stretch the capabilities of leaders and help them not only to lead the possible but also to delight in it.

These three approaches pose different questions, adopting multiple perspectives and systems.

\section{Value Configurations: Higher Education as a Service}

In particular the perspective adopted determines the respective value configuration (see Figure 2 "Higher Education Value Framework"). In this context, research, as a specialist area of activity within higher education is aimed at providing a "value shop" (Stabell \& Fjeldstad, 1998, p.415), because the best possible answers to the research questions are primarily identified at the beginning of the research process, which always attempt to grasp a problem in the social reality. The value shop is the only logic to provide necessary solutions for protecting value creation within the educational network. In order to generate value, a value shop works cyclically and iteratively, instead of sequentially (Schafmeister \& Ellert, 2013, p.92). The goal of a value shop, however, can only be achieved by a corresponding value network. Related to research, this value configuration implies, for example, collaboration and cocreation with other researchers who work on publications for the business or scientific community. The literature research and integration of existing information on a specific research topic is also relevant. The value network is characterized by the simultaneous interaction of the network actors, such as colleagues, partners or customers, and generates competitive advantage through vertical and horizontal integration, which is produced by intermediation and co-creation tools (Stabell \& Fjeldstad, 1998, p.413). The larger the researcher's network, the greater the impact. Due to a high number of network actors, however, the risk of unpredictable problems and the possibility of incapacitation increases. In order to manage and avoid uncertainties and problems that threaten the generation of value within the 
value network, researchers must often change the dominant value configuration. At this point, the value shop comes into action, by providing the necessary solutions to protect value creation within the network. From the logic of our theoretical framework described above (SD-logic, co-creation, value configuration value network, psychology of learning, state and action orientation), it is important to create a visual learning tool that provides both state- and action-oriented students with appropriate decision support, in complex systems and networks associated with increased uncertainty.

\section{Mapping Techniques and Visualizations Reducing Complexity}

In the context of developing the Empirical Research Map, we were looking for a suitable tool to map the entire empirical research process in all its complexity. The mapping technique and visualization proved to be especially suitable, because visualizations are very effective for understanding complex systems, anticipating long range and secondary effects and solving complex problems. More and more newspapers and magazines nowadays resort to infographics for the mediation and simplification of complex information. Knieper (1997, p. 584), for example, even calls for more "courage" in visualizing, because infographics increase the information potential of daily newspapers. Through visualization, complex issues can be received faster and better, taking into account the "KISS - Keep it simple and stupid" principle (Bingel, 2010, p.20). According to Klimsa (2002, p. 5) (translated from Bingel, 2010, p.10), "information coming via two input channels (eyes and ears) are positioned better". Ballstaedt (2012, p.20) argues that visualizations are "analytical pictures ... because they expose connections in reality". Furthermore, he states that pictures "are able to communicate content better than texts alone" (Ballstaedt, 2011, p.15). This fact is confirmed by learningand cognition psychology research. Based on these and other findings from concept mapping and information design research, the Empirical Research Map was developed through co-creation. Concept Maps yield a structured representation of knowledge and information in a visual-spatial format (Cox, 1999, p.348). Tergan (2005, p. 1) attributes the development of Concept Mapping to Novak and Gowin (1984), who described it for the first time in their book "Learning How to Learn": "Concept Maps are graphical representations, which are able to depict relations and hierarchies between elements" (Tergan, 2005, p. 2). Lima (2011, p. 12) again emphasizes:

Information visualization is widely used as a tool for understanding data i.e., discovering patterns, connections, and structures. Since science is the area of human activity targeting the discovery of new knowledge about the world through systematic methods - such as experimentation, mathematical modeling, simulation - visualization now functions as another of these methods. What distinguishes this new method is that it 
also firmly belongs to design - it involves the visual presentation of data in a way that facilitates the perception of patterns.

To facilitate significant decisions, problem solving and the management of uncertainty in empirical research process for both state and action-oriented students, the Empirical Research Map was developed, based on the presented theoretical insights.

The Empirical Research Map is intended to provide useful preconditions for decisions from a holistic perspective, depicting the system in its entirety, enabling problem-solving processes with better system understanding, reducing complexity and enhancing the researcher's role perceptions. One fundamental point from Heuer (1999, p.20) refers to the importance of tools and techniques that gear the analyst's mind to apply higher levels of critical thinking [because they] can substantially improve analysis on complex issues on which information is incomplete, ambiguous, and often deliberately distorted. Key examples of such intellectual devices include techniques for structuring information, challenging assumptions, and exploring alternative interpretations.

By visualizing a systematically structured process and chunking information, the Empirical Research Map, as an intermediate tool, provides orientation and a navigation aid, since the associated long-range and secondary effects can be anticipated better and, in changing contexts, one can react more quickly so to as ultimately achieve the research goals in a safe way. From a didactic perspective, the Empirical Research Map offers additional value to researching and teaching researchers and students, taking into account the six basic principles of visualization: color, uniformity, shortness, order, suitability and simplicity (Bingel, 2010, p.19).

\section{Methodology for the Construction of the Higher Education Value Framework}

For the construction of our higher education value framework, a qualitative research approach was chosen. By using Delphi technique for expert group discussions, it was possible to gain useful insights and new perspective on higher education. After extensive interviews with in total seven experts from different scientific fields (e.g. service science, psychology, general management, higher education and business studies), we were able to discover and then to adapt the following framework from service science in the context of higher education.

\section{Outcome: The Higher Education Value Framework}

As already described above, the SD-logic provides insights that have the potential to improve our understanding of higher education issues and, as shown further down, aid in the development of appropriate tools. We therefore 
use the SD-logic as a theoretical foundation for our conceptual model and aim to propose, based on Woratschek, Horbel and Popps' (2014, p.12) "Sport Value Framework", a "Higher Education Value Framework" that enables a thorough understanding of higher education phenomena. This framework consists of ten foundational premises, which are described below in Figure 2.

Figure 2. The Higher Education Value Framework

\section{Higher Education Value Framework Basic understanding of Higher Education}

(1) Understanding networks, developing problem solving competencies through

1 teaching and learning, the ability for collaborative working and ethical values are the core values of higher education.

2 Service is the fundamental basis of exchange in higher education.

3 Educational goods (products and services) are vehicles for service provision and the actor must trust the quality of practices so as to create value.

(4) Higher education facilities and customers/students can only offer value propositions and actors can engage with them.

(5) Higher education facilities create value propositions mainly through the

5 configuration of a value network.

(6) Every complex value-network has value co-creators and co-destructors. To

6 manage the co-destructor, the value configuration changes to a value shop. Value is always co-created by higher education facilities, students and other
actors.

8 Co-created value is always value-in-use and value-in-context taking place on live or digital learning platforms for cognitive development.

9 The actors' focus within the value-proposition anatomy determines the higher

9 education strategy decision for horizontal and vertical integration.

The role of higher education facilities, students and other stakeholders is to

10 integrate the resources or practices within their specific networks to co-create value.

Source: Authors.

1. In an increasingly complex, progressively networked and more uncertain world in which knowledge, job descriptions and requirements and consequently education programs have an ever shorter half-life, a comprehensive system and network understanding, problem-solving skills and the ability to work collaboratively are of increasing importance. Higher education is characterized by equipping students with competences and ethical values for coping with an uncertain future. 
These competences are conveyed on the basis of the configuration 'value network' through closely linked, collaborative teaching and learning processes and the interplay of many other stakeholders and learning environments.

2. As mentioned, service is, according to the SD-logic, the fundamental basis for exchange in the field of higher education. The SD-logic defines service "as the applied knowledge of the actors involved in value creation and sees it as the basis of all economic exchange" (Woratschek, Horbel, \& Popp, 2014, p. 14).

3. Moreover, in the SD-logic applied knowledge is the reason why exchange exists, and why products (e.g. courses of study) and services are only one aspect of applied knowledge. Following this logic further and applying it to the field of higher education, education goods are "vehicles that convey the applied knowledge and skills of the actors involved" (Woratschek, Horbel, \& Popp, 2014, p.14). They provide students "with the opportunity to achieve higher-order benefits or needs". The involved actors must also trust the quality of the methods, for value to be created.

4. Higher education facilities are also a platform for using all the involved actors as a means of providing their unique value configuration. The students' value configuration is, for example, that they shape the campus atmosphere decisively, through their physical presence, and enrollment decision, as well as through attending classes or events, getting involved, discussing, evaluating, reflecting, organizing, criticizing, acquiring skills and knowledge etc.

5. Point 5 in turn accesses the previously mentioned configuration value network, because only this value configuration is suitable for analysis and describes the value proposition of higher education facilities - in contrast to Porter's value chain - taking into account the abovementioned collaborative process and the networking of all actors.

6. According to Woratschek, Horbel and Popp (2014, p.17) through the interactions of customers, in our case, students, value is created within social groups as well. Not only at sports events, but also during academic studies, subjects often act within a group (e.g. course or learning groups) or are influenced by others. In addition, students contribute through co-creation to shaping the reputation of a higher education Facility, for example, by recommending their alma mater. In addition, the presence and opinions of fellow students enhances to perceptions of service quality and consequently to perceptions of value propositions.

7. Value in higher education facilities always emerges from co-creation and the interaction of all involved actors. For example, students contribute to value creation by participating in the classroom, while lecturers and professors in turn make their contribution to through their experience, knowledge and skills. Higher education facilities create value by providing the facilities, personnel and appropriate educational 
offerings, which they actively promote, thereby communicating the values of higher education. Often, the parents of students also contribute to value creation by supporting their children in the choice of university or course of study, for example.

8. Value creation in higher education facilities always requires an interrelationship of different social actors, with varying and individual consequences. According to Woratschek, Horbel and Popp (2014, p.18) the generation of value is not merely the product of an act of purchase: "Every actor has to integrate his/her own resources with the value propositions of the other actors". Value creation is determined according to the motivations and specific interests of an actor. Since, moreover, value is derived from the actual use of a product or service, for example, by participating in class in higher education facilities on live or digital learning platforms, one talks of "value-in-use". Not to be disregarded is the context within value creation takes place. The context is crucial for the perceptions, significance and weighting of individual value creations, which can therefore vary from actor to actor. According to Woratschek, Horbel and Popp, "the resources that can potentially be integrated into the process of value co-creation depends on the specific context. Consequently, value propositions can be more valuable in one context, and less so in another". If one considers these findings and applies them to the field of higher education, a completely different value is created by frontal teaching in a crowded lecture hall, than in small groups with intensive supervision and the possibility of intensive exchange. However, in another course with a different content focus, this may be quite different.

9. Every actor has a specific or different focus within the value proposition anatomy (also see Skalen, Gummerus, von Koskull, \& Magnusson, 2015, p.149), that determines higher education strategy decision for vertical and horizontal integration. To give an example: Students in a specific course might have to solve several problems (focus on "problem solving"), while the lecturer focusses on knowledge sharing. In order to harmonize these two different value propositions, it is important to identify the different value propositions of the different actors in order to ensure high quality integration decisions and reactions.

10. The last aspect of the higher education value framework refers to the "network-with-network model of value creation" (Woratschek, Horbel, \& Popp, 2014, p.19) and states that the role of all stakeholders in the field of higher education is that of integrating resources from specific networks, in order to create value through co-creation. Besides students, teaching staff and the service staff, lots of other stakeholders are integrated at universities, for example the state in the form of the Ministry of Science or project partners and employers from the free economy, to name just a few. 


\section{Methodology for the Construction of the Higher Education Learning and Teaching Tool}

Based on qualitative research strategies (Merriam, 2009) and the above described value framework, the conceptual model of our higher education learning and teaching tool, the Empirical Research Map, in fact arises from non-empirical research. According to Selamat and Hashem (2008, p.41) "qualitative research approaches are designed to help researchers understand people and the social and cultural contexts within which they live". A qualitative research approach, as a first step, turned out to be the most perceptive way to construct this conceptual model. The following 12 steps adopt the logic of constructivism and interpretivism. The Empirical Research Map was developed from Selamat and Hashem's "qualitative decision trail":

1. Reading and writing different perspectives from didactics in higher education, the psychology of learning, project- and risk management, uncertainty management, concept mapping, information design, complex problem solving and value creation logic.

2. Hearing and writing different research on different perspectives

3. Connecting different elements to a mapping story and constructing central elements

4. Guiding conversations through the story

5. Hermeneutic interpretation - developing meaning with different theory elements

6. Learning through dialogue

7. Checking logic

8. Using extracts from the second guided conversation with respondents

9. Visually constructing different degrees of detail

10. Detailing a proofing circle for maximum value

11. Using guided conversations through visualization and reflecting on problems with experts

12. Final construction of the research map.

Step 11 describes a qualitative interview research approach. According to Hohl (1998, p.496), qualitative interview methods are based on a hermeneutic understanding of science. This considers the human being as a meaningconstituting being who creates his concepts of life and situation interpretations in social relations and changes them in ongoing social negotiation processes. In expert interviews with 12 experts from six fields of the social sciences and humanities, which took between 30 to 120 minutes, new insights in terms of didactics in higher education and visualisations could be gained, in order to develop a conceptual model according to the socio-scientific empirical research process. The expert interview, used particularly often according to Meuser and Nagel (2009, p.465) in educational research, appeared to be a very suitable qualitative method for the construction of this conceptual model in this context. 


\section{Outcome: Higher Education Teaching- and Learning-Tool: The Empirical Research Map}

The developers' intention is not to reinvent the research-wheel or to reject widely accepted findings. All elements included in the Empirical Research Map already existed and are discussed extensively in the literature. Rather, the aim is to bundle all process steps relevant for the research success in a strategically meaningful way, and to bring them together logically with a structure, and to depict them as one networked process. The Empirical Research Map depicts two fundamental processes that influence each other and that are both embedded in an ever-changing context:

1. The research strategy, which determines the role of the researcher for the process and also the type of research 'toolbox'.

2. The research process, beginning with the identification and formulation of research goals, up to the development of new tools and concepts for the working world, and publications for the scientific community, which finally result in new phenomena and new research goals.

Lines, strokes and arrows show connections between the single steps of procedure and processes. A carefully chosen color system also shows the networking of the system, which in turn allows a better anticipation of longrange and secondary effects and play-through scenarios. For example, the researcher's role (research strategy "researcher role" - color code "orange") has an influence on the empirical approach (also displayed in orange). The Empirical Research Map can be downloaded under www.researchmap.info.

\section{Implications and Conclusion}

The authors are aware that holistic models in many social science disciplines are currently not 'state of the art', but rather focus on partial models that are then explored more deeply and developed further. However, the Empirical Research Map is well suited as a visualized holistic intermediatemodel for understanding the research system in the social sciences, offering a navigational aid for both state- and action-oriented students. This facilitates the anticipation of long-range and secondary effects and also helps teachers in the field of higher education to convey complex system research more effectively to their students.

A further step has to be an empirical, comparative quantitative analysis method with multiple test groups, to determine whether research-specific questions can be answered more effectively with the Empirical Research Map as a teaching tool.

Implications for the field of higher education are as follows. The depth of understanding and reception of research education must be optimized with regard to the development of learning and teaching. Using SD-logic as a new 
perspective for a better understanding of higher education issues in general can be helpful and insightful.

In addition, in the field of higher education there is a need for new ways of dealing with increased complexity, anticipating long-range and secondary effects, as well as developing a conceptual model for decision facilitation in the research process. It should be noted that the Empiric Research Map covers only the socio-scientific research area, and excludes other scientific disciplines, not being suitable for their specific research processes. But also for other scientific disciplines, we recommend a holistic visualization, which makes it easier for students to gain an overall system understanding and to reduce complexity. Moreover, the rapidly advancing digitalization, with all its new requirements, usage habits and possibilities, must not be disregarded. The Empirical Research Map must "move with the times" and continue to develop, also digitally, for example through interactive design and co-creation. Furthermore, the effectiveness of learning success by means of the Empirical Research Map, have to be measured empirically.

\section{References}

Achi, Z., \& Berger, J. (2015). Delighting in the possible. Mckinsey. Retrieved from http://bit.ly/2hR5BZw.

Akaka, M. A., Corsaro, D., Kelleher, C., Lusch, R.F., Maglio, P.P., Seo, Y., \& Vargo, S. L. (2013). The role of symbols in value co-creation. Submission for the 2013 Naples Forum on Service. Retrieved from http://bit.ly/2iDEFxB.

Amit, R., \& Zott, C. (2001). Value creation in E-Business. Strategic Management Journal, 22(6-7), 493-520. doi:10.1002/smj.187.

Ashill, N., Naumann, E., Sirdeshmukh, D., \& Williams, P. (2013). Key account management and the relationship lifecycle: Towards a framework for collaboration. American University of Sharjah. School of Business \& Management Working Paper Series. Retrieved from http://bit.ly/2i4HAMs.

Ballstaedt, S.-P. (2011). Visualisieren [Visualisation]. Stuttgart: UTB.

Bildungsserver Rheinland-Pfalz (2015). Studienskript Lernpsychologie. Staatliches Studienseminar für das lehramt an grundschulen [Lecture Note Learning Psychology. Governmental seminar teaching degree for secondary schools]. Retrieved from http://bit.ly/2iZ7EbI.

Bingel, C. (2012). Visualisieren [Visualisation]. Freiburg: Haufe.

Blüthmann, I., Lepa, S., \& Thiel, F. (2012). Überfordert, verwählt, enttäuscht oder strategisch? eine typologie vorzeitig exmatrikulierter bachelorstudierender [Overstrained, disappointed, wrong decision or strategically - A typology of prematurely exmatriculated bachelor students]. Zeitschrift Für Pädagogik, 58(1), 89-108.

Boes, A., Kämpf, T., \& Marrs, K. (2013). Zukunftsforum 2. Neue Formen Der Industrialisierung. Arbeitskreis "Herausforderung Unternehmen 2.n. Nachhaltige strategien für eine global vernetzte ökonomie" [Future Forum 2. New forms of industrialisation. research group challenges for corporations 2.n. Sustainable strategies for a global networked economy]. München: ISF München. 
Broadbent, D. E. (1977). Levels, hierarchies, and the locus of control. Quarterly Journal of Experimental Psychology, 29(2), 181-201. doi:10.1080/1464074 7708400596.

Castells, M. (2010). The rise of the network society. Second edition with a new preface. West Sussex: Wiley-Blackwell.

Chandler, J. D., \& Lusch, R.F. (2015). Service systems: A Broadened framework and research agenda on value propositions, engagement, and service experience. Journal of Service Research, 18(1), 6-22. doi:10.1177/1094670514537709.

Chandler, J. D., \& Vargo, S.L. (2011). Contextualization and value-in-context: How context frames exchange. Marketing Theory, 11(1), 35-49. doi:10.1177/14705 93110393713.

Clark, R. E., Keith, H., \& Early, S. (2006). Motivational challenges experienced in highly complex learning environments. In E. Jan \& R.E. Clark (Eds.), Handling Complexity in Learning Environments (pp. 27-43). Oxford, UK: Elsevier.

Cox, R. (1999). Representation, construction, externalised cognition and individual differences. Learning and Instruction, 9(4), 343-363.

Dörner, D. (2012). Die logik des misslingens: Strategisches Denken in komplexen situationen [The logic of failure: Strategic thinking in complex situations]. Rowohlt: Hamburg.

Dörner, D., \& Wearing, A.J. (1995). Complex problem-solving: Towards a (computersimulated) theory. In P.A. Frensch \& J.Funke (Eds.), Complex Problem Solving (pp. 65-99), Hillsdale, N.J.: L. Erlbaum Associates.

Dörner, D., Drewes, U., \& Reither, F. (1975). Über das Problemlösen in sehr komplexen Realitätsbereichen [About problem solving in very complex reality spheres]. In W.H. Tack (Ed.), Bericht über den 29. Kongreß der Dgfps In Salzburg 1974, Band 1 (pp. 339-340). Göttingen: Hogrefe.

Dörner, D. (1983). Lohhausen: Vom umgang mit unbestimmtheit und komplexität [Lohhausen: About dealing with uncertainty and complexity]. Bern: Huber.

Dörner, D. (1979). Problemlösen als informationsverarbeitung [Problem solving as information processing]. Stuttgart: Kohlhammer.

Ellert, G., Schafmeister, G., Mueller, F., Dallwig, S., \& Phelan, S. (2014). The influence of alcohol on advertising perception and recall during a sports viewing experience. European Sport Management Quarterly, 14(2), 153-170. doi:10. 1080/16184742.2014.884151.

Falk-Frühbrodt, C. (2015). Lerntypen II - Jeder Mensch Lernt Anders [Learner Types II - Every Individual learns differently]. Institut für integrative Lerntherapie und Weiterbildung. Retrieved from http://bit.ly/2iyFxDr.

Fischer, A., Greiff, S., \& Funke, J. (2012). The process of solving complex problems. The Journal of Problem Solving, 4(1), 19-42. doi:10.7771/1932-6246.1118.

Frensch, P.A., \& Funke, J. (1995). Complex problem solving. Hillsdale, N.J.: L. Erlbaum Associates.

Goldstone, R. L., \& Pizlo, Z. (2009). New perspectives on human problem solving. The Journal of Problem Solving, 2(2), 1-5. doi:10.7771/1932-6246.1055.

Heuer, R.J. Jr. (1999). Psychology of intelligence analysis. Center for the Study of Intelligence. Central Intelligence Agency. Retrieved from http://bit.ly/1xy07nA.

Hohl, J. (1998). Qualitative methoden [Qualitative methods]. In S. Grubitzsch \& K.Weber (Eds.), Psychologische Grundbegriffe (pp. 495-498). Reinbek: Rowohlt.

Kazén, M., Kaschel, R., \& Kuhl, J. (2008). Individual differences in intention initiation under demanding conditions: Interactive effects of state vs. action orientation and enactment difficulty . Journal of Research in Personality 42(1), 693-715. 
Kainz, E. (2011). Bologna aus der sicht der studierenden zwischen idee und umsetzung [Bologna from the students' point of view between idea and implementation]. University of Vienna. Retrieved from http://bit.ly/2j3u77s.

Kaplan, R. S., \& Norton, D.P. (1997). Balanced Scorecard. Stuttgart: SchäfferPoeschel.

Klimsa, P. (2002). Multimedianutzung aus psychologischer und didaktischer Sicht [Multimedia use from a psychological and didactical perspective]. In L.J. Issing, \& P. Klimsa (Ed.). Information Und Lernen Mit Multimedia Und Internet (3rd ed.). Weinheim: Beltz PVU.

Knieper, T. (1997). Mehr Mut zur Visualisierung: Infographiken steigern das Informationspotential der Tageszeitung [More courage for visualisation: infographics increase newspapers' information potential]. In G. Bentele (Ed.), Aktuelle Entstehung von Öffentlichkeit (pp. 577-586). Konstanz: UVK Medien.

Kuhl, J. (n.d.). Handlungs- und Lageorientierung. Wie lernt man, seine Gefühle zu steuern? [Action- Vs. State-Orientation. How to learn regulating emotions?]. Deutsche Messi Selbsthilfe. Retrieved from http://bit.ly/2hMUZLd.

Lima, M. (2011). Visual Complexity. New York: Princeton Architectural Press.

Lusch, R. F. (2011). Reframing supply chain management: A service-dominant logic perspective. Journal of Supply Chain Management, 47(1), 14-18. doi:10.1111/ j.1745-493x.2010.03211.x.

Lusch, R. F., \& Vargo, S.L. (2006). The service-dominant logic of marketing. Armonk, N.Y.: M.E. Sharpe.

Merriam, S.B., (2009). Qualitative research. San Francisco: Jossey-Bass.

Merton, R. (2013). Innovation risk: How to make smarter decisions. Harvard Business Review. Retrieved from http://bit.ly/2hP366R.

Meuser, M., \& Nagel, U. (2009). Das Experteninterview - Konzeptionelle grundlagen und methodische anlage [The expert interview - Conceptual foundations and methodical attachment]. In S. Pickel, D. Jahn, H.-J. Lauth, \& G. Pickel (Eds.), Methoden der vergleichenden Politik- und Sozialwissenschaft. Neue Entwicklungen und Anwendungen (pp. 465-479). Wiesbaden: VS-Verlag.

Porter, M. E. (1985). Competitive Advantage. New York: Free Press.

Quast, U. (2011). Lernermerkmale, lernertypen, lernverhalten: aspekte der differentiellen lernpsychologie für lehrende und lernende [Learner characteristics, learner types, learning behaviour: Aspects of differential psychology of learning for lecturers and learners]. Bern: Lang.

Rogers, D. L. (2000). A paradigm shift: Technology integration for higher education in the new millennium. Educational Technology Review, 13(1), 19-33.

Sargut, G., \& McGrath, R. (2011). Learning to live with complexity. Harvard Business Review. Retrieved from http://bit.ly/1QBqtLG.

Schafmeister, G., \& Ellert, G. (2013). Wertschöpfung und Sportübertragungen - Was macht Sportrechte wertvoll? [Value creation and sports broadcasting - What makes sports laws valuable?]. In A. Hebbel-Seeger, T. Horky \& K. Pohle (Eds.), Crossmediale Kommunikation und Verwertung von Sportveranstaltungen (pp. 9199). Aachen: Meyer and Meyer Sport.

Selamat, M. H., \& Hashim, A.H. (2009). A qualitative decision trail in the hermeneutic analysis: Evidence from the case study. International Journal of Business and Management, 3(3), 41-55. doi:10.5539/ijbm.v3n3p41.

Sheth, J. N., \& Uslay, C. (2007). Implications of the revised definition of marketing: From exchange to value creation. Journal of Public Policy \& Marketing, 26(2), 302-307. doi:10.1509/jppm.26.2.302. 
Skalen, P., Gummerus, J., von Koskull, C., \& Magnusson, P.R. (2015). Exploring value propositions and service innovation: A service-dominant logic study. Journal of the Academy of Marketing Science, 43(2), 137-158.

Stabell, C. B., \& Fjeldstad, O.D. (1998). Configuring value for competitive advantage: On chains, shops, and networks. Strategic Management Journal, 19(5), 413-437.

Stoelsnes, R.R., \& Bea, R.G. (2005). Uncertainty management of general conditions in a project. Risk Management (Bas), 7(2), 19-35. doi:10.1057/palgrave. rm. 8240210 .

Tergan, S-O. (2005). Concept maps \& e-learning. [e-teaching Reader version]. Retrieved from http://bit.ly/2j3vdnN.

Thompson, J. D. (1967). Organizations in action. New York: McGraw-Hill.

Van Horne, J. (1966). Capital-budgeting decisions involving combinations of risky investments. Management Science, 13(2), 84-92. doi:10.1287/mnsc.13.2.b84.

Vargo, S.L., Lusch, R.F., \& Akaka, M.A. (2010). Advancing service science with service dominant logic: Clarifications and conceptual development. In P.P. Maglio, C.A. Kieliszewski, \& J.C. Spohrer (Eds.), Service Science: Research and Innovations in the Service Economy (pp. 133-156). New York: Springer Science. doi:10.1007/978-1-4419-1628-0_8.

Vargo, S.L., \& Lusch, R.F. (2008). Service-dominant logic: Continuing the evolution. Journal of the Academy Of Marketing Science, 36(1), 1-10. doi:10.1007/s11747007-0069-6.

Vargo, S.L., \& Lusch, R.F. (2006). Service-dominant logic. What it is, what it is not, what it might be. In R.F. Lusch \& S.L. Vargo (Eds.), The Service-Dominant Logic of Marketing. Dialog, Debate, and Directions (pp. 43-56), Armonk NY: M.E. Sharpe.

Vargo, S.L., \& Lusch, R.F. (2004). Evolving to a new dominant logic for marketing. Journal of Marketing, 68(1), 1-17. doi:10.1509/jmkg.68.1.1.24036.

Vester, F. (2014). Denken, lernen, vergessen. Was geht in unserem kopf vor, wie lernt das gehirn, und wann lässt es uns im stich? (36th ed.) [Thinking, learning, forgetting. What Happens inside our head, how does the brain learn and when does it desert us?]. München: dtv.

Ward, S., \& Chapman, C. (2003). Transforming project risk management into project uncertainty management. International Journal of Project Management, 21(2), 97-105. doi:10.1016/s0263-7863(01)00080-1.

Woratschek, H., Horbel, C., \& Popp, B. (2014). The sport value framework - A new fundamental logic for analyses in sport management. European Sport Management Quarterly, 14(1), 6-24. doi:10.1080/16184742.2013.865776.

Wörfel, F., Gusy, B., \& Lohmann, K. (2014). Schützt selbstmitgefühl studierende vor burnout? [Does self-compassion protect students from burnout?]. Prävention Und Gesundheitsförderung, 10(1), 49-54. doi:10.1007/s11553-014-0471-0.

Zillien, N. (2009). Digitale ungleichheit [Digital inequality]. Wiesbaden: VS-Verlag. 